Mesned İlahiyat Araştırmaları Dergisi / The Journal of Mesned of Theological Studies ISSN 2667-7075| e-ISSN 2687-3605 | https://dergipark.org.tr/tr/pub/mesned

Cilt (Vol.) 12 Sayı (Issue 2) Güz - (Autumn) 2021

ARAŞTIRMA MAKALESI | RESEARCH ARTICLE

(Bu makalenin intihal içermediği benzerlik tarama programlarıyla teyit edilmiştir. / The similarity that this article does not contain plagiarism, has been confirmed by plagiarism checker programs.)

Doi: $10.51605 /$ mesned.1014595

Gönderim Tarihi: 25.10 .2021 Kabul Tarihi: 24.12.2021

\title{
Ebu'l-Hasan el-Mâverdî'ye Göre Kıyasın Tanımı ve Türleri*
}

\author{
-Definition and Types of Qiyas According to Ebu'l-Hasan al-Mawardi-
}

\section{Kazim Yusufoğlu**}

Atıf/Citation: Yusufoğlu, Kazim. “Ebu'l-Hasan el-Mâverdî’ye Göre Kıyas ve Türleri/ Definition and Types of Qiyas According to Ebu'l-Hasan al-Mawardi". Mesned Illahiyat Araștırmaları Dergisi/ The Journal of Mesned of Theological Studies, (Güz 2021-2): 333-356.

Öz:

Sâfî̂ fakih Ebu'l-Hasan el-Mâverdî, Türkiye'de daha çok devlet teorisi, siyaset ve ahlak alanındaki çalışmalarıyla ön plana çıksa da ortaya koyduğu eserlerle Şâfiî fikıh geleneği içerisinde füru-i fıkıh alanında da otorite kabul edilmektedir. Bununla birlikte fıkıh usulü ilminin konularını da incelemeye tabi tutmuștur. Bu konuda müstakil herhangi bir eser kaleme almamıștır. Ancak füru-i fikha dair telif ettiği el-Hâvi'l-Kebir adındaki eserinin edebu'l-kâdî ana bölümünde kadının hüküm verirken istişarede bulunması gereken kişinin içtihat ehlinden olması gerektiğini ifade etmiștir. Bu bağlamda yüz küsur sayfadan fazla fikıh usulü ilminin temel konularını ana hatlarıyla ele almıștır. Burada kendinden önceki tartıșmaları da dikkate alarak fıkıh usulü konularını ele almıs ve orijinal bazı tespit ve değerlendirmelerde bulunmuştur. Mâverdî̀nin, özgün tespitlerde bulunduğu konulardan birisi de kıyastır. Kıyas, müstakil bir delil olarak mı yoksa müçtehidin bir faaliyeti olarak mı kabul edileceği tartısmasına bağlı olarak iki farklı șekilde tanımlanmıștır. Kıyası müstakil bir delil olarak kabul eden usûlcüler onu; "asl ile fer'in, aslın hükmünden çlkartılan (istinbât) illette istivâ'/müsâvî (eșit) olmalarıdır" seklinde anlayışlarına uygun lafızlar kullanarak tanımlarken, müçtehidin faaliyeti olarak gören usûlcüler ise, "fer'i, aralarındaki ortak vasıf sebebiyle aslın hükmünde asla hamletmek/ispat etmek/ilhak etmek/tadiye etmek/tesviye etmek/reddetmektir." biçiminde düșüncelerine uygun kelimeler kullanarak tanımlamışlardır. İkinci tanım hicri yedinci asra kadar usûlcüler tarafindan savunulurken, birinci tanım Âmidî ile birlikte savunulmaya bașlanmıștır. Mâverdî kıyası "aralarındaki ortak illet sebebiyle hükümde fer'i asla ilhâk (ilave) etmektir." șeklinde tanımlayarak onu, müçtehidin faaliyeti olarak gördügünü ortaya koymuştur. Mâverdî, kıyasın hükme delaletinin

* Bu Makale, “Mâverdî'nin Fıkıh Usûlü Anlayışı” isimli yüksek lisans tezimizden üretilmiştir.

* Doktora Öğrencisi, İnönü Üniversitesi Sosyal Bilimler Enstitüsü, k_yusufoglu@hotmail.com. Ocrid: 0000-0002-4434-5508. 
kuvvet derecesini dikkate alarak taksimata tabi tutmuştur. Kıyası güçlüden zayıfa doğru türlere ayıran Mâverdî, toplam on iki kısım tespit etmiștir. O, kıyası ilk önce mana kıyası ve șebeh kıyası şeklinde iki ana kısma ayırmıștır. Mâverdî, mana kıyasının iki şekilde tanımlanabileceğini ifade etmektedir. Bunlardan ilki "fer'in, hükmünü aslın manasından (illet) alması"; ikincisi ise "fer'in, yalnızca bir aslının bulunması ve hükmünü onun manasından almasıdır". Mana kıyasını celî ve hafî şeklinde iki alt kısma ayıran Mâverdî, celî kıyası "fer'deki illetin asıldaki illetten daha fazla (güçlü) olduğu kıyas" şeklinde tanımlamış ve üç gruba ayırarak incelemeye tabi tutmuştur. Celî kıyasın her üç türüne dayanılarak icmâın oluşabileceğini, bunlarla umumî lafızların tahsis edilebileceğini ifade eden Mâverdî, bunlardan bir kısmı ile hükmün neshedilebileceğini ileri sürmüștür. Hâfî kıyası "manası (illeti) gizli olup istidlâl yoluyla ancak bilinebilen ve fer'deki manası asıldaki manasına eşit olan kıyas" biçiminde tanımlayan Mâverdî, bunu celî kıyas gibi üç alt kısma ayırmıștır. Hafî kıyasın türleri sağlamlık bakımından eşit sevide olmadığı için bunlardan bir kısmı ile icmâ gerçekleştirilir, hâkimin verdiği hüküm bozulabilir ve bunlarla umumi lafızlar tahsis edilebilirken bazıları ile böyle bir işlem yapılamamaktadır. Şebeh kıyasının; birisi "fer'in, hükmünü asla benzemesinden aldığı kıyas"; diğeri "fer'in benzetilebileceği birden çok aslın bulunduğu, bunlardan benzerliğin en güçlü olduğu asla benzetildiği kıyas" biçiminde iki farklı șekilde tanımlanabileceğini ileri süren Mâverdî, bunun tahkik kıyası ve takrîb kıyası şeklinde iki alt kısma ayrıldığını ifade etmiştir. Tahkik kıyasını "benzerliğin, hükümlerinde (asl ile fer') olması" șeklinde tanımladıktan sonra bunu da üç kısma ayırarak incelemeye tabi tutmuştur. Mâverdî, takrîb kıyasını "benzerliğin (aslın) niteliklerinde meydana geldiği kıyas" olarak tanımlamış ve bir önceki kıyas türü gibi bunu da üç kısma ayırmıştır. Bunun sonucunda altısı mana kıyası altı tane de şebeh kıyası olmak üzere toplam on iki kıyas türü ortaya çıkmıştır. Mâverdî, yalnızca teori düzeyinde değil, somut örneklerle de kıyasın tüm kısımlarını açılamaya çalışmıştır. Anlașılmasının zor olduğuna kani olduğu meselelerde șer'î örneklerle yetinmemiş hem akli hem de şer'î örneklerle konuyu izah etmeye çalışmıştır. Mâverdî, farklı yaklaşımların söz konusu olduğu yerlerde bunları ele almaktan uzak durmamıştır. 0 , incelemeye tabi tuttuğu konuları temellendirmekle yetinmemiş, bir kısım itirazları da ele alarak cevaplamaya çalışmıștır. Bu bağlamda özellikle Hanefiler tarafından İmam Şâfiî̀ye yapılan itirazları değerlendirerek cevaplamaya çalışmıştır. Mâverdî’nin kıyasın taksimatı konusundaki görüşü diğer usûlcülerin görüşleriyle farklılık arz etmektedir.

Anahtar Kelimeler: Mâverdî, Mana kıyası, Şebeh kıyası, Celî kıyas, Hafî kıyas.

\section{Abstract:}

Although Shafi'i jurist Ebu'l-Hasan al-Mawardi comes to the forefront with his works in the field of state theory, politics and morality in Turkey, he is accepted as an authority in the field of furu-i figh within the Shafi'i fiqh tradition. However, he also examined the subjects of the science of fiqh. He did not write any independent work on this subject, but in the main part of his work named alHavi'l-Kebir, which he wrote on furu-i fiqh, he stated that the person who should be consulted while judge making a judgment should be from the people of ijtihad and in this context More than a hundred-odd pages have covered the main subjects of the science of fiqh. Here, he discussed the issues of fiqh, taking into account the previous discussions, and made some original determinations and evaluations. One of the subjects on which he made original determinations is qiyas. Qiyas has been defined in two different ways depending on the argument that it is accepted as a stand-alone evidence and that it is accepted as an activity of a mujtahid. The methodologists, who accept the comparison as an independent evidence; While defining the asl and fer'in using words appropriate to their understanding as (istinbât) istiwa'/similar (equal) in malady, which is deduced from the ruling of the original, the methodologists, who see it as the activity of the mujtahid, say, "the secondary will never be in the same quality as the original due to the common quality between them". They defined it with the word "hammer". While the second definition was defended by the methodists until the seventh century AH, the first definition started to be defended with Âmidî. Mâverdî qiyas says, "the primary annexation (addition) in the judgment due to the common cause between them." he described it as a mujtahid's activity. Mawardi divided the qiyas by taking into account the degree of strength of the indication of judgment. Al-Mawardi, who divided the qiyas into types from strong to weak, identified a total of twelve parts. He first divided qiyas into two main parts as mana qiyas and shabeh qiyas. Mâverdî states that qiyas meaning can be defined in two ways. The first of these is "fer's taking its decision from the original meaning"; the second is that "fer has only one 
original and takes its decision from its meaning". Mawardi, who divided the mana qiyas into two sub-sections as celî and hafî, defined celi qiyas as "the qiyas in which the malady in fer is more (strong) than the original malady" and divided it into three groups and subjected it to examination. Mâverdî stated that consensus can be formed based on all three types of celi qiyas and that general words can be allocated with them, and argued that some of them can abrogate the judgment. Maverdi, who defines Hâfî qiyas as "qiyas whose meaning (malady) is hidden and which can only be known through inference and whose meaning in fer is equal to its original meaning", divided it into three sub-sections like celi qiyas. Since the types of hafi qiyas are not equal in terms of soundness, ijma is carried out with some of them, the judgment given by the judge may be overturned and general words can be allocated with them, while such a procedure cannot be done with some of them. Sebeh qiyas; one of them is "the qiyas that a person takes because his judgment never resembles"; Maverdi, who claimed that it can be defined in two different ways, the other being "there are more than one original to which a person can be compared, and the similarity is the strongest, and the analogy to which it is never compared", stated that it is divided into two sub-sections as verificaiton qiyas and taqrîb qiyas. After defining the syllogism verification as "similarity in its provisions (asl and fer')", he divided it into three parts and subjected it to examination. Mawardi defined the syllogism of taqrîb as "the qiyas in which the similarity (original) occurs in the qualities" and, like the previous type of syllogism, divided it into three parts. As a result of this, a total of twelve types of qiyas emerged, six of which are mana qiyas and six are shebeh qiyas and tried to answer some of the objections that were not content with justifying the issues he examined.

Keywords: Mâverdi, Mana qiyas, Shebeh qiyas, Celî qiyas, Hafi qiyas.

\section{GíRiș}

Bir taraftan İslam dininin son ve evrensel din olmasından dolayı onun hukukunun her devir ve şartta Müslümanların karşılaşacakları sorunları çözüme kavuşturma zorunluluğu, diğer taraftan ise İslam'ın iki temel dayanağı olan Kur'an ve sünnette bulunan dinî hükümlerin sınırlı olması, Müslümanları ortaya çıkan yeni sorunlara bir yöntem dâhilinde çözüm bulmaya sevk etmiştir. Bu yöntem, herhangi bir şer'î hüküm hakkında zannî bilgiye ulaşabilmek için bütün gücünü harcamak anlamına gelen içtihattır.

İstihsân, 1stıslâh, maslahat-1 mürsele, istikrâ', sahabe kavli vb. gibi delilleri bünyesinde barındıran ve çok geniş bir yelpazeye sahip olan içtihadın ana omurgasını kıyas teşkil etmektedir. Kıyasın delil olarak kabul edilmesi hususunda Zahiri mezhebi dışında herhangi bir görüş ayrılığı bulunmamakla birlikte kıyası oluşturan unsurlar, bu unsurlardan her birisinin şartları, kıyasın tanımı ve kısımları gibi konularda usûlcüler arasında görüş ayrılığı bulunmaktadır.

Bu makalede Şâfiî fakih Ebu'l-Hasan el-Mâverdî'nin (ö. 450/1058) kıyasın tanımı ve türleri konusundaki görüşleri ele alınacaktır. Mâverdî'nin fıkıh usulüne dair müstakil herhangi bir eseri bulunmamaktadır. Ancak Şâfii mezhebinin temel kaynaklarından kabul edilen Müzenî'ye (ö. 264/878) ait el-Muhtasar'1 şerh etmek için kaleme aldığı el-Hâvi'l-Kebîr isimli eserinin on altıncı cildinde 
fıkıh usulünün tüm konularına dair görüşlerini beyan etmiştir. Mâverdî, burada kıyasın tanımını yapmış ve kıyasın kısımları konusunda geniş izahlar yapmiştır. Bu makalede el-Hâvi'l-Kebîr'in ilgili bölümü esas alınarak Mâverdî'nin kıyasın tanımı ve türleri konusundaki yaklaşımı ortaya konulacaktır.

\section{MÂVERDÎ'YE GÖRE KIYASIN TANIMI}

Usûlcülerin en çok üzerinde durdukları hususlardan biri de ele aldıkları konuların tanımıdır. Zira tanım, tanımı yapılan şeyin mahiyetini ortaya koyduğu gibi onunla ilgili temel nitelikleri ve tanım yapanın konuyla ilgili tasavvurunu da ortaya koymaktadır. Tanımın en önemli özelliklerinden birisi kendilerinden olan fertleri içermesi, olmayanları da dışlamasıdır. Daha teknik bir ifadeyle söyleyecek olursak tanımların efradını cami ağyarını mâni olmaları gerekmektedir. Bu sebeple özellikle bünyesinde farklı konuları barındıran kavramların tanımı hususunda çok sıkı davranıldığı gibi temkinli de davranılmıştır.

Mâverdî, kıyas konusuna içtihat ve istinbât şeklinde iki mukaddime ile giriş yapmayı tercih etmiştir. İmam Şâfii'nin kıyas ile içtihadı eşitlediğine dair iddialar Mâverdî'nin bu iki mukaddime ile kıyas konusuna giriş yapmasına sebep olmuştur. Mâverdî böyle bir mukaddime ile içtihadın kıyastan ibaret olduğu şeklindeki iddianın Şâfii'ye nispetinin sahih olmadığını vurgulamak istemiştir. ${ }^{1}$ Mâverdî içtihat ve istinbât mukaddimelerini ele alıp inceledikten sonra kıyasın tanımına geçmiştir.

Ebu'l-Hasan Ali b. Muhammed b. Habib Mâverdî, Edebu'l-Kâdî, thk. Muhyî Hilâl es-Serhân (Bağdâd: Matbaatu'l-İrşâd, 1971), 1: 489-490; Mehmet Birsin, “Ebu'l-Hasan el-Mâverdî'nin Bilgi Anlayışı”, İnönü Üniversitesi Uluslararası Sosyal Bilimler Dergisi 2/1 (2019): 63. Mâverdî, Şâfiî́nin er-Risâle'deki ifadelerin yanlış anlaşıldığına işaret etse de Şâfiî usulcüler arasında Şâfiî'nin kıyas ile ictihad kelimelerini aynı manada kullandığı kanaati hakimdir. Ancak Şâfiî usulcülerin çoğu mezhep imamlarına bu konuda katılmadıklarını beyan etmekten geri de durmamışlardır. Bu konudaki tartışmalar için bkz: Metin Yiğit, "İmâm Şâfiî̀'de Arapça Vurgusu ve Lafız-Mana Dengesi", Dicle Üniversitesi İlahiyat Fakültesi Dergisi 11/2 (2009): 69; İhsan Akay, Şâfiì Usûl Geleneğinde İmâm Şâfiì'ye Muhalif Görüşler (İstanbul: Ensar, 2018), 143-147; Ahmet Temizkan, İmam Şâfiì̀nin Usûl Anlayışında Şer" î Delillerin Teâruzu ve Çözüm Yolları (Dicle Üniversitesi SBE, 2019), 78-81. 
Sözlükte “ölçmek, ölçek, eşit olmak, değerlendirmek, görüş, teşbih, mümâselet, isabet, iki şeyi bir araya getirmek" 2 gibi manalara gelen kıyas kelimesinin delalet ettiği manalar takdîr (bir şeyin miktarının belirlenmesi) ve müsavât (bir şeyin başka bir şeye eşit olması) şeklinde iki noktada birleştiği kabul edilmektedir. ${ }^{3}$ Mâverdî kıyas kelimesinin sözlükte "mümaselet" ve "isâbet" anlamlarına geldiğini, bu iki anlamın da kavramsal anlama uygun olduğunu ifade etmektedir. ${ }^{4}$

Kıyasın gerçek manada tanımının mümkün olup olmadığ 1 ile ilgili tartışmayı bir tarafa bırakırsak ${ }^{5}$ yapılan tanımları iki kısma ayırmak mümkündür. Diğer bir ifadeyle, usûlcüler tarafından asıl ile fer' arasındaki ilişkiyi ifade etme konusunda iki farklı kavram grubu kullanılmaktadır. Bunlardan ilki, hamletmek, ispat etmek, ilhâk etmek, ta'diye etmek, tesviye yapmak, reddetmek vb. ikincisi ise, istivâ', musâvât vb. kavramlardır. Birinci gruba göre kıyasın tanımı şöyle yapılabilir: "Fer'i, aralarındaki ortak vasıf sebebiyle aslın hükmünde asla hamletmek/ispat etmek/ilhak etmek/tadiye etmek/tesviye etmek/reddetmektir." İkinci gruba göre ise "asl ile fer'in, aslın hükmünden çıartılan (istinbât) illette istivâ' etmeleri / müsâvồ (eşit) olmalarıdır" şeklinde tanımlanabilir. Birinci grup kavramları,

2 İbn Manzûr, Lisanü'l-Arab, thk. Abdullah Ali el-Kebir v.dğr. (Kahire: Darul Mearif, t.y.), 5: 3793-3794; Zemahşerî, Ebu'l-Kasım Mahmud b. ömer, Esasü'l- Belağa (Beyrut: Daru'lKutubi'l-ïlmiyye, 1998), 2: 114.

3 Seyfeddîn Âmidî, el-ïhkam fî Usûli'l-Ahkâm, thk. Abdullah b. Ali eş-Şehrânî v.dğr. (Riyâd: Daru'l-Fadîle, 2016), 4: 1617; Abdülkerim en-Nemle, el-Muhezzeb fî Usûli'l-Mukâren (Riyad: Mektebetü'r-Rüşd, 1999), 4: 1815.

4 Ebu'l-Hasan Ali b. Muhammed b. Habib el-Mâverdî, Edebu'l-Kâdî, thk. Muhyî Hilâl esSerhân (Bağdâd: Matbaatu'l-İrşâd, 1971), 1: 556-557. Örneğin; Araplar iki şey arasındaki benzerliği ifade etmek istediklerinde; “هذا قياس هذا lar. Kıyas işlemi; "hükümde birbirine benzeyen iki meseleyi bir araya toplamak" olduğu için kök anlamıyla aralarında bir münasebet vardır. Bir diğer kök anlamı olan "الإصابة: Elde etmek, kazanmak"la ilgili olarak Araplar bir şeyi elde ettiklerinde; قست الشيء: Kazandım” ifadesini kullanırlar. Kıyas, "kendisi ile hüküm elde edilen” anlamına geldiği için bu kök anlamıla uygunluğu söz konusudur. Edebü'l-kâdı̂’yi tahkik eden Muhyî Hilâl Es-Serhân, “hiçbir Arapça sözlükte kıyasın isabet anlamına geldiğine dair bir bilgiyi bulamadığını, bu anlamın ya müellif zamanında hâkim olan örfi bir anlam olduğu ya da kendisinin Arap dilini araştırma sonucunda böyle bir manayı tespit ettiğini tahmin ediyoruz." şeklinde bir görüş beyan etmiştir. Bkz: Serhân, Edebü'l-kâdî, I, 557 .

5 Bedruddîn b. Bahâdır ez-Zerkeşî, el-Bahru'l-Muhît fî̀ Usûli'l-Fıkıh, thk. Abdussettar Ebû Gudde (Kuveyt: Vezaretü'l-Evkaf ve'ş-Şuunü'l-İslamiyye, 1992), 5: 6-7; Nemle, elMuhezzeb, 4: 1823-1824. Kıyasın tanımının mümkün olduğunu savunanlar ile mümkün olmadığını savunanların delilleri için bkz: Nemle, el-Muhezzeb, 4: 1823-1824. 
Cessâs (ö. 370/981), Ebû Bekir el-Bâkıllânî (ö. 403/1013), Ebu'l-Huseyn el-Basrî (ö. 436/1044), Ebû İshâk eş-Şîrâzî (ö. 476/1083), Cüveynî (ö. 478/1085), Serahsî (ö. 483/1090), Gazzâlî (ö. 505/1111) ve Fahreddîn er-Râzî (ö. 606/1210) gibi usûlcü-

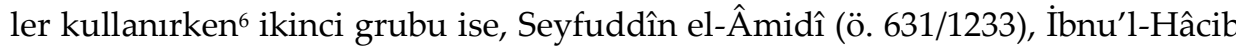
(ö. 646/1249), İbnu'l-Hümâm (ö. 861/1457) ve İbn Abdişşekûr (ö. 1119/1707) gibi usûlcüler kullanmıştır.?

Mâverdî birinci grup kavramlardan biri olan ilhâk kavramını kullanarak

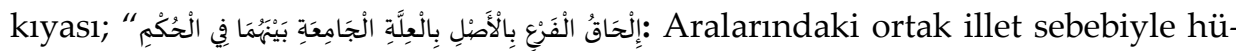
kümde fer'i asla ilhâk (ilave) etmektir." ${ }^{\prime}$ şeklinde tanımlamıştır.

Kıyası tanımlamada kullanılan kavramlar rastgele seçilen kavramlar değildir. Bu kavramlar asl ile fer' arasında kurulan ilişkide müçtehidin rolüne bağlı olarak kullanılmıştır. Başka bir ifadeyle kıyas müstakil bir delil midir yoksa müçtehidin faaliyeti midir? Usûlcüler arasında bu konudaki görüş ayrılığı kıyasın tanımında farklı kavramların kullanılmasına sebep teşkil etmektedir. Kıyas işlemini müçtehidin faaliyeti olarak gören usûlcüler, asl ile fer' arasındaki ilişkiyi ifade ederken hamletmek, ispat etmek, ilhak etmek, tadiye etmek, tesviye etmek, reddetmek şeklinde müçtehidin aktifliğini ifade eden kavramları kullanmış-

6 Ahmed b. Ali er-Râzî el-Cessâs, el-Fusûl fi'l-Usûl, thk. Uceyl Câsim en-Neşemî (Kuveyt: Vezâretü'l-Evkâf ve'ş-Şuûni'l-İslamiyye, 1994), 4: 99; İmâmu'l-Harameyn el-Cüveynî, elBurhân fì Usûli'l-Fıkh, thk. Sâlih b. Muhammed b. Aviza (Beyrut: Dâru'l-Kütübi'l-İlmiyye, 1997), 2: 5; Ebû'l-Hüseyn Muhammed b. Ali el-Basrî, Kitabu'l-Mu'temed fî Usûli'l-Fıkh, thk. Muhammed Hamidullah (Dımeşk: el-Me'hedu'l-İlmiyyi'l-Fransî li'd-Dirâsâti'l-Arabî, 1964), 2: 1032; Ebû İshâk İbrahim b. Ali eş-Şirâzî, el-Lum'a fi Usûli'l-Fıkh, thk. Muhyiddin Dîb mistu ve Yusuf Ali Bedivi (Beyrût: Dâru ibn Kesir, 1995), 198; Şemsü'l-Eimme Muhammed b. Ahmed es-Serahsî, Usûü̈'s-Serahsî, thk. Ebû'l-Vefâ el-Afgânî (Beyrût: Daru'lKutubi'l-İlmiyye, 1993), 2: 118; Ebû Hâmid Muhâmmed b. Muhammed el-Gazzâlî, elMustasfâ min İlmi'l-Usûl thk: Süleyman el-Eşkar (Beyrut: Müessesetü'r-Risale, 2010), 2: 236; Fahreddin Muhammed b. Ömer Hüseyin er-Râzî, el-Mahsûl fî İlmi-Usûli'l-Fikh, thk. Taha Câbir Feyyâz Alvânî (Beyrût: Müessesetü'r-Risale, t.y.), 5: 5 .

7 Âmidî, el-İhkâm, 4: 1627-1628; Cemâleddîn Ebî Ömer Osman İbnu'l-Hâcib, Muhasaru'lMüntehe's-Sûli ve'l-Emel fî İlmeyi'l-Usûli ve'l-Cedel, thk. Nezîr Hamâd (Beyrut: Dâru ibn Hazm, 2006), 2: 1025-1026; Kemâleddîn Muhammaed b. Abdilvahid İbnu'l-Hümâm, etTahrîr fì usûli'l-Fıkh el-Câmii Beyne İstilâhayi'l-Haneyiyyeti ve'ş-Şâfiiyye (Mısır: Matbaatu Mustafa el-Babîel-Halebî, 1351), 415; Abdulali Muhammed b. Nizâmeddîn Leknevî, Fevâtihu'rRahamût bi Şerhi Müsellemi's-Sübût, thk. Abdullah Mahmut b. Ömer (Beyrut: Dâru'lKutubi'l-İlmiyye, 2002), 2: 297.

8 Mâverdî, Edebu'l-Kâdî, 1: 555. 
lardır. ${ }^{9}$ Bu usûlcülere göre kıyas müçtehidin faaliyetidir, ancak onun varlığ gerçekleşebilir. Bu sebeple tanımda aslın hükmünü fer'e vermenin müçtehidin faaliyeti olduğunu ortaya koymak için bu anlama havi kelimeler kullanılmıştır. Yukarıdaki kelimelerin tümünde bu mana bulunmaktadır. Kıyası, müçtehidin bir faaliyeti olarak değil, Kur'an ve sünnet gibi müstakil bir delil olarak gören usûlcüler ise, istivấ, musâvât gibi kavramları kullanmayı tercih etmişlerdir. Kullanılan bu lafızlardan da anlaşılacağı üzere bu usûlcülere göre kıyas müçtehidin bir faaliyeti olmadığından, onun (müçtehidin) görevi, yalnızca hakkında nass bulunmayan meselelerin hükmünün aralarındaki ortak illet sebebiyle hakkında nass bulunan meselelere eşit olduğunu açıklamaktan ibarettir. Yani asl ile fer' hükümde tamamen eşittirler. Müçtehidin görevi yalnızca bu eşitliği açıklamaktan ibarettir. Müçtehidin buradaki konumu herhangi bir ayetin hükme delaletini açıklama konusundaki konumu ile aynıdır. ${ }^{10}$

Mâverdî, kıyasın tanımında ithâk (ilave) kavramını kullanarak kıyası müstakil bir delil olarak görmediğini aksine müçtehidin faaliyeti olarak telakki ettiğini ortaya koymuştur. ${ }^{11}$ Zira İhâk eylemi bu eylemi yapanın (kıyas yapan müçtehit) varlığını zorunlu olarak gerektirmektedir.

\section{MÂVERDÎ'YE GÖRE KIYASIN TÜRLERİ}

Fıkıh usulünün her bir konusu müstakil olarak önemli olduğu gibi bu konuların birbirleriyle ilişkisi de önemlidir. Bunun en bariz örneği kıyastır. Kıyasın hücciyeti, unsurları vb. konular kadar icmâ, nesih, umumî lafızların tahsisi, hâkimin verdiği hüküm ile ilişkisi de önemlidir. Müçtehidin bir faaliyeti olarak görülen kıyasın ana unsuru olan illet ve asıl ile fer' arasındaki ilişki tüm kıyas işlemlerinde aynı kuvvette bulanmamaktadır. Kıyas sonucunda tespit edilen fer'in hükmü, kıyas türüne göre farklılık arz etmektedir. Bu sebeple usûlcüler kıyası farklı taksimatlara tabi tutmuşlardır. Bunun sonucunda hem fer'in hükmü tespit edilecek hem de tespit edilen bu hüküm ile icmâ, nesih, umumî lafızların tahsisi ve hâkimin verdiği hüküm arasındaki ilişki belirlenecektir. Mâverdî, tüm bu hususları göz önünde bulundurarak kıyası farklı türlere ayırmıştır.

\footnotetext{
Nemle, el-Muhezzeb, 4: 1828.

Nemle, el-Muhezzeb, 4: 1825-1829.

Mâverdî, Edebu'l-Kâdî, 1: 555.
} 
Fıkıh usulünün tedvin dönemi olarak kabul edilen hicri üçüncü asırdan olgunlaşma dönemi olarak kabul edilen beşince asra kadar ${ }^{12}$ kıyasın taksimi ve türleri hususunda usûlcüler tarafından ortaya konulan yaklaşımlar arasında Mâverdî'ninki dikkat çekmektedir. Onun kıyas için yaptığı taksimatın en çok dikkat çeken yönü hem sistematik olması hem de türleri arasındaki kuvvet derecesini ortaya koymak için onu alt kısımlara ayırıp detaylandırmasıdır. ${ }^{13}$

Mâverdî, kıyası mana (illet) kıyası ve şebeh kıyası olmak üzere ikiye ayırmıştır. Ancak kıyasın bu iki çeşidinin tanımı konusunda Şâfiî usûlcüler arasında iki farklı yaklaşımın bulunduğunu ifade etmektedir. Birinci yaklaşıma göre fer'in, hükmünü aslın manasından (illet) aldığı kıyasa mana kıyası; fer'in, hükmünü asla benzemesinden aldığı kıyasa ise şebeh kıyası denir. İkinci yaklaşıma göre, fer'in, yalnızca bir aslının olduğu ve hükmünü onun manasından aldığı kıyasa mana kıyası; fer'in benzetilebileceği birden çok aslın bulunduğu, bunlardan benzerliğin en güçlü olduğu asla benzetildiği kıyasa şebeh kıyası adını alır. Mâverdî, iki yaklaşıma göre de mana kıyasının şebeh kıyasından daha güçlü olduğunu ifade etmektedir. ${ }^{14}$

\subsection{Mana Kıyası}

Mâverdî, mana ve şebeh kıyaslarının tanımı hususunda Şâfiî usûlcüleri arasında bulunan iki farklı yaklaşımı zikrettikten sonra bu iki yaklaşım arasında herhangi bir tercihte bulunmadan bunları alt kısımlara ayırarak ele almışırı. İlk önce mana kıyasını ele alan Mâverdî, bunu celî kıyas ve hafì kıyas şeklinde iki kısma ayırarak incelemeye tabi tutmuştur.

\subsubsection{Celî Kıyas}

Sözlükte "açık olan, gizli olmayan"15 manasına gelen celî lafzı kıyas kelimesi ile birlikte Mâverdî tarafından; "فيكون معناه في الفع زائدا علي معنى الاصل: Fer'deki ille-

12 Fıkıh usulünün gelişim aşamaları ve her bir aşamadaki temel kaynaklar hakkında geniş bilgi için bkz: Abdulvahhab İbrahim Ebû Süleyman, el-Fikru'l-Usûlî-Dirâse Tahliliyye Nakdiyye (Cidde: Daru'ş-Şurûk, 1983), 96-442.

13 Mâverdî'den sonra kıyası detaylı bir şekilde sistematik olarak Seyfuddîn el-Âmidî ele almıştır. Bkz Âmidî, el-ïhkâm, 5: 1823-1831.

14 Mâverdî, Edebu'l-Kâdî, 1: 586.

15 Zemahşerî, Esasü'l- Belă̆a, 1: 146. 
tin asıldaki illetten daha fazla (güçlü) olduğu kıyas"16 şeklinde tanımlanmıştır. Mâverdî, celî kıyası üç kısma ayırarak tetkik etmiştir.

1. İstidlâl olmaksızın nassın zahirinden manası (illeti) anlaşılabilen ve aslına muhalif bir hükmün gelmesi (teabbud) caiz olmayan celî kıyas. Mâverdî; celî kıyasın bu türü için ebeveyne öf demeyi yasaklayan ayeti örnek olarak zik-

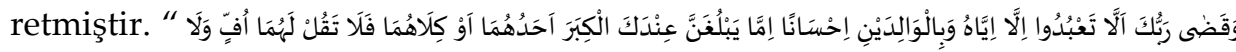

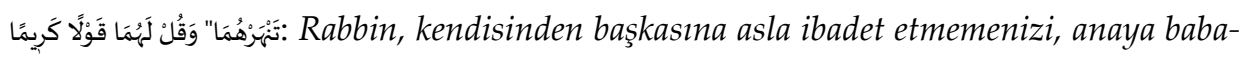
ya iyi davranmanızı kesin olarak emretti. Ĕ̆er onlardan biri, ya da her ikisi senin yanında ihtiyarlık çă̆ına ulaşırsa, sakın onlara "öf!" bile deme; onları azarlama, onlara tatl ve güzel söz söyle" (İsra 17/23) ayeti evladın ana-babasına "öf!" demesini yasakladığı gibi onlara sövmeyi ve eziyet etmeyi de yasaklamıştır. Sövme ve eziyet, öffe kıyaslanarak yasaklanmıştır. Bu kıyas işleminde istidlâl olmaksızın illet nassın zahirinden anlaşılmış ve asla (öf demenin yasaklanması) aykırı şer'î herhangi bir hüküm de gelmemiştir. Yani hiç kimse ayette "öf" demek yasaklanmış diyerek vurmanın caiz olduğunu söylememiştir. Mâverdî; celî kıyasın bu kısmını en güçlü kıyas olarak nitelendirmiştir. Zira celî kıyasın bu türünde nasta açıkça zikredilmese de fer'in ona dâhil olduğu kabul edilmektedir. ${ }^{17}$

Nazzâm (ö. 231/845), Dâvûd ez-Zâhirî (ö. 270/884), Ebu'l-Ferec enNerevânî (ö. 390/1000) ve Vezîr el-Mağribî (ö. 418/1027) gibi kıyası delil olarak kabul etmeyen usûlcüler de ayette sarahaten zikredilmeyen ancak öften daha ağır olan fiillerin de ebeveyne karşı yasaklandığını kabul etmektedirler. ${ }^{18}$ Mâverdî, kıyası delil olarak kabul etmeyen usûlcüler arasında istidlal olmaksızın nassın zahirinden anlaşılan hükmü nitelendirme hususunda farklılığın söz konusu olduğunu ifade etmektedir. Bu usûlcülerden bir kısmı böyle bir işlemi nass olarak nitelendirirken bazıları da tenbih olarak isimlendirmiştir. ${ }^{19}$

Kıyası delil olarak kabul eden usûlcüler de bunu kıyas olarak kabul etme hususunda hemfikir değildirler. ${ }^{20}$ Kıyası delil olarak kabul eden usûlcülerin çoğunun celî kıyasın bu türünü kıyas olarak adlandırmadığını ifade eden

16 Mâverdî, Edebu'l-Kâdî, 1: 586-587.

17 Mâverdî, Edebu'l-Kâdî, 1: 587-588.

18 Mâverdî, Edebu'l-Kâdî, 1: 559-560,588.

19 Mâverdî, Edebu'l-Kâdî, 1: 588.

20 Bu hususta Ayritılı bilgi için bkz: Zerkeşî, Bahru'l-Muhît, 5: 37-38; Akay, Şâfî̀ Usûl Geleneğinde İmâm Şâfiî’ye Muhalif Görüşler, 163-167. 
Mâverdî, bunlardan bir kısmının bu işlemi "mefhumu'l-hitab" bazılarının da "fahvâ'l- kelâm" olarak isimlendirdiğini belirtmektedir. ${ }^{21}$

Bu şekilde hükme ulaşmayı kıyas olarak değerlendiren Şâfiî̀ye bazı usûlcüler kıyasın; hükmü nasta belirtilmeyen kapalı meselelerin istidlâl ile hükmünün belirlenmesinden ibaret olduğunu, açı olup istidlâle ihtiyaç duyulmadan hükmü tespit edilebilen bir durumun kıyas olarak isimlendirilemeyeceğini ileri sürerek itirazda bulunmuşlardır. ${ }^{22}$ Mâverdî, böyle bir itirazın iki yönden hatalı olduğunu ifade etmektedir: Birincisi, nass ile ortaya konulan meselenin hükmü nassın isminden anlaşılırken kıyas ile ortaya konulan meselenin hükmü nassın dışındaki şeyin isminden anlaşılmaktadır. Başka bir ifadeyle aslın hükmünü nass ortaya koyarken, fer'in hükmünü illet ortaya koymaktadır. Yukarıdaki örnekte aynı durum söz konusudur. Dövme lafzı, öf lafzını kapsamadığı gibi öf lafzı da dövme ve sövme lafızlarını kapsamamaktadır. Bunlardan her birisi diğerinin içermediği manayı içermektedir. Dolayısıyla ebeveyne karşı öften daha ağır fiillerin yasaklanması öf lafzı ile değil manası (illet) ile gerçekleşmiştir. İkincisi ise, manalar da tıpkı isimler gibidirler. Bir kısmı istidlale ihtiyaç duymayacak kadar açık olup herkes tarafından anlaşılabilirken bazıları da kapalı (hafi) olup ancak işin ehli tarafından istidlal sonucu anlaşılabilir. İsimlerin kapalılık ve açıklık açısından farklı oluşu nass olmalarına engel olmadığı gibi, manaların (illetler) da kapalılık ve açıklık açısından farklı oluşları bunlar aracılığıyla gerçekleştirilecek işlemin kıyas olmasına engel değildir. ${ }^{23}$

Celî kıyasın bu türü ile umumi (genel) lafızların tahsis edilebileceği hususunda Şâfiî mezhebinde herhangi bir görüş ayrılığının bulunmadığını ifade eden Mâverdî, bununla hükmün nesh edilip edilmeyeceği konusunda ihtilafın bulunduğunu belirtmektedir. Çoğunluğa göre, celî kıyasın bu türü ile nesh işlemi yapılamaz. Bunların temel gerekçesi; kıyasın nassın fer'i oluşudur. Fer'in, aslı neshetmesi düşünülemez. Ebû Ali b. Ebî Hüreyre'nin (ö. 345/956) de içinde bulunduğu Şâfiîlerin bir kısmı, celî kıyasın bu türü ile hükmün neshedilebileceğini ileri sürmüşlerdir. Bunların temel argümanları, bu kıyas işleminde, asla muhalif şer'î bir hükmün gelmesinin (teabbud) caiz olmamasının, fer'i asıl

21 Mâverdî, Edebü'l-Kâdî, 1: 588-589.

22 Mâverdî, Edebu'l-Kâdî, 1: 589.

23 Mâverdî, Edebu'l-Kâdî, 1: 589-592. 
(nass) ile aynı konuma çıkarmasıdır. Fer', nass ile aynı konumda olduğuna göre aynen nass gibi fer' ile de neshedilebilir. ${ }^{24}$

Mâverdî'ye göre, celî kıyasın bu türü, Kur'an'a dayanılarak yapılmışsa sünneti değil Kur'an'ı, sünnete dayanılarak yapılmışsa Kur'an'ı değil sünneti neshedebilir. ${ }^{25}$

2. İstidlâl olmaksızın nassın zahirinden manası (illeti) anlaşılabilen ancak aslına muhalif bir hükmün gelmesi (teabbud) caiz olan celî kıyas. Mâverdî, celî kıyasın bu türü için Hz. Peygamber'in, körlüğü açıkça belli olan tek gözlü, topallığı iyice belli olan topal hayvanların kurban edilmesini yasaklamasını örnek olarak zikretmiştir. ${ }^{26}$ İstidlâle ihtiyaç duyulmaksızın iki gözü de kör olan hayvan hadiste zikredilen tek gözü kör olana, iki ayağı kesik olan da topal olana kıyas edilerek bu özellikteki hayvanların kurban edilemeyeceği sonucuna varılmıştır. Fakat tek gözlü ve topal olan hayvanın kurban edilemeyeceğine dair mezkûr nass ile hüküm konulurken, kör ve iki bacağı kesik olan hayvanın kurban edilebileceğine dair bir hükmün gelmesi de mümkündür. ${ }^{27}$

Kıyası delil olarak kabul etmeyen usûlcülerin, yukarıdaki hükmü değerlendirme hususunda farklı anlayışlara sahip olduklarını ifade eden Mâverdî, bunlardan bir kısmı, yalnızca hadiste anlatılan kusurları kurbana engel kabul ederken, bazıları da mezkûr sonuca kıyas ile değil, nassın iması ile varıldığını iddia ettiklerini ileri sürmüştür. Yani birinci gruba göre tek gözlü ve topal hayvan kurban edilemez ancak nasta zikredilmediği için kör ve topal hayvanlar kurban edilebilir. İkinci gruba göre ise, hem tek gözlü ve tek ayaklı hem de iki gözü kör ve iki ayağı kesik hayvanlar kurban edilemezler. Bunlar bu sonuca kıyas işlemi ile değil, nassın iması ile vardıklarını ileri sürmüşlerdir. ${ }^{28}$

Mâverdî, Şâfiî mezhebinde celî kıyasın bu türü ile umumi lafızların tahsis edilebileceğini ancak böyle bir kıyas ile herhangi bir hükmün neshedilemeyeceğini, bu konuda tüm Şâfiîlerin müttefik olduklarını ifade etmektedir.

\footnotetext{
Mâverdî, Edebü'l-Kâdî, 1: 592.

Mâverdî, Edebü'l-Kâdî, 1: 592.

Tirmizî, Edâhî, 5.

Mâverdî, Edebu'l-Kâdî, 1: 592-594.

Mâverdî, Edebü'l-Kâdî, 1: 592-594.
} 
Mâverdî’ye göre celî kıyasın bu çeşidi ile nesh işleminin yapılamamasının nedeni, aslına aykırı bir hükmün gelmesinin mümkün (caiz) olmasıdır. ${ }^{29}$

3. İlleti açık istidlâl ile nassın zahirinden anlaşılan ve nazar kurallarına göre bilinen celî kıyas. Mâverdî, cuma namazı saatinde alışverişi yasaklayan يَا أَّها

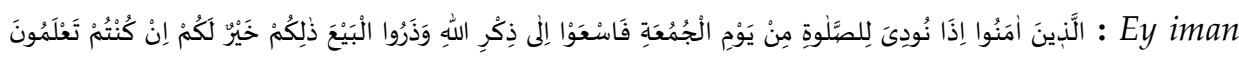
edenler! Cuma günü namaz için çă̆r yapıldığı zaman, hemen Allah'ın zikrine koşun ve alışverişi bırakın. Eğer bilirseniz bu, sizin için daha hayırlıdır" (Cuma 62/9.) ayetini celî kıyasın bu türü için örnek olarak zikretmiştir. Cuma günü alışverişin yasaklanmasının illeti, alışverişin cuma namazına gitmeye engel olmasıdır. Bu sebeple nikâh akdi, icâre vb. cuma namazına gitmeye engel olan tüm fiillerin alışverişe kıyas edilerek yasak olduğu hükmüne varılmıştır. Bu kıyas işleminde illet, açık istidlâl ile nassın zahirinden anlaşılmaktadır. ${ }^{30}$

Celî kıyasın bu türü ile nesih işleminin yapılamayacağını ifade eden Mâverdî, umumi lafızların tahsis edilip edilemeyeceği konusunda Şâfiî mezhebinde görüş ayrılığının bulunmasıyla birlikte çoğunluk tarafından bu tür celî kıyas ile tahsisin caiz görüldüğünü belirtmektedir. Tahsisin yapılamayacağını iddia edenlere göre illet, istidlâl ile tespit edilmesi sebebiyle açık olmaktan çıkmaktadır. Mâverdî böyle bir gerekçenin yersiz olduğunu ileri sürmüştür. Ona göre, illetin istidlâl ile açık olması ile istidlâlsiz açık olması arasında herhangi bir fark bulunmaktadır. Önemli olan onun anlaşılır ve açık olmasıdır. ${ }^{31}$

Mâverdî, celî kıyasın üç çeşidine dayanılarak icmâın oluşturulabileceğini, bu tür kıyaslara aykırı olması durumunda hâkimlerin verdiği hükümlerin bozulacağını ileri sürerek bu konuya son vermiş̧ir. ${ }^{32}$

\subsubsection{Hafî Kıyas}

Sözlükte "gizli olan, açık olmayan" 33 manasına gelen hafî lafzı, kıyas ke-

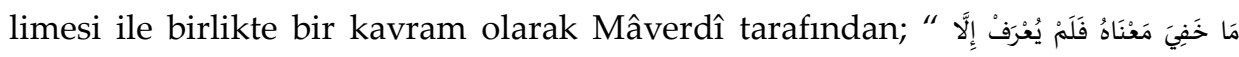

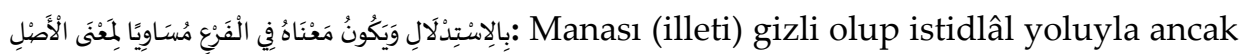

29 Mâverdî, Edebü'l-Kâdî, 1: 594.

30 Mâverdî, Edebü'l-Kâdî, 1: 594-595.

31 Mâverdî, Edebü'l-Kâdî, 1: 595-596.

32 Mâverdî, Edebu'l-Kâdî, 1: 596.

33 Zemahşerî, Esasü'l- Belă̆a, 1: 260. 
bilinebilen ve fer'deki manası asıldaki manasına eşit olan"34 şeklinde tanımlanmıştır.

Mâverdî, hafî kıyası, celî kıyas gibi üç kısma ayırarak incelemeye tabi tutmuştur.

1. Manası (illeti) kolay anlaşılan/lâih hafî kıyas: Manası (illeti) belirgin olan ve herkesçe kabul edilen bir istidlâl ile bilinen kıyastır. Mâverdî, hafî kıya-

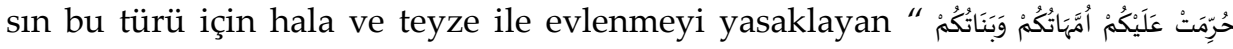

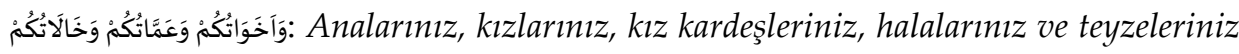
ile evlenmeniz size haram kılındı" (Nisa 4/23) ayetini örnek olarak zikretmiştir. Bu ayette evlenilmesi haram kılınan halalara ve teyzelere akrabalık bağında müşterek olmaları ortak vasfı sebebiyle anne ve babalar kıyas edilerek haram kılınmıştır. ${ }^{35}$

Hafî kiyasın bu türü için Mâverdî'nin verdiği örneklerden birisi de küçük

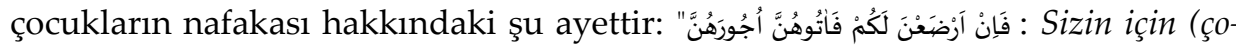
cuğu) emzirirlerse (emzirme) ücretlerini de verin." (Talak 65/6) Çocukların nafakasının vacip kılınmasının illeti acziyettir. Yaşlı olan babaların nafakası aralarındaki ortak illet olan acziyetten dolayı çocuklarınkine kıyas edilmiştir. Mezkûr iki ayetteki hükümlere kıyas yapılması tespit edilen illet sebebiyledir. Bu kıyas işleminde illet herkesçe kabul edilen bir istidlâl ile kolay anlaşılmıştır. ${ }^{36}$

Mâverdî tarafından hafî kıyasın bu türü celî kıyasa benzetilmiştir. Bu sebepten hareketle o, kıyasın bu türüne dayanılarak icmâın gerçekleşebileceğini ve hâkimin verdiği hükmün bu kıyasa ters olması durumunda bozulacağını ileri sürmüştür. Mâverdî, kıyasın bu türü ile umumi lafızların tahsis edilip edilmeyeceği konusunda biri olumlu diğeri olumsuz olmak üzere iki görüş bulunduğunu ifade etmekte ancak herhangi bir tercihte bulunmaktadır. ${ }^{37}$

2. Manası (illeti) zor anlaşılan/gâmid hafî kıyas: Hafî kıyasın bu türü, illeti istidlâl ile zor anlaşılan, bu sebeple hakkında farklı anlayışların ortaya çıktığı bir kıyas çeşididir. Mâverdî'ye göre buradaki illetin zor anlaşılmasının nedeni, tespit edilen illetlerin birbirleriyle çelişmesidir. Mâverdî, kıyasın bu çeşidi için

34 Mâverdî, Edebu'l-Kâdî̀, 1: 596.

35 Mâverdî, Edebu'l-Kâdî, 1: 596-597.

36 Mâverdî, Edebu'l-Kâdî, 1: 597.

37 Mâverdî, Edebü'l-Kâdî, 1: 596-597. 
nass ile sabit olan buğdayın ribevî madde oluşunu örnek olarak zikretmiştir. Buğdayın ribevîliğinin illeti hususunda mezhepler arasında görüş ayrılığ konusudur: Hanefiler, cins birliği ile birlikte keyl ve vezni, Şafiîler cins birliği ile birlikte gida maddesi olma, Malikiler ise cins birliği ile birlikte depolanabilen gıda maddesi olma vasıfların illet olarak belirlemişlerdir. ${ }^{38}$ Her mezhebin tespit ettiği illet diğerinin tespit ettiği illetten farklı sonuçlar doğurmaktadır. Bu sebeple her birisi diğerinin tespit ettiği illete itirazda bulunmuştur. Örneğin Şâfiî bir müçtehit, ikisi de yiyecek maddesi olmaları sebebiyle meyveyi buğdaya kıyas ederek meyvenin fazladan satışının caiz olmadığı hükmüne varacaktır. Buna karşın Maliki müçtehit, asıldaki illetin yiyecek maddesi olma vasfının olmadığını, illetin saklanabilen gıda maddesi olma vasfı olduğunu, bu illetin fer' olan meyvede bulunmadığını, meyvenin buğdaya kıyas edilemeyeceğini, dolayısıyla meyvenin meyve karşılığında fazla olarak takas edilmesinin caiz olduğunu ileri sürerek itirazda bulunacaktır. ${ }^{39}$ Hanefi bir müçtehitin, tartılan madde olma ortak illetinden dolayı arpaya kıyasla demirin fazlalıkla satışının caiz olmadığına hükmetmesine karşılık Şâfiî müçtehit, tartı birliğini illet olarak kabul etmediklerini, aksine illetin yiyecek maddesi olma vasfı olduğunu, dolayısıyla demirin demir karşılığında fazlalıkla satışının caiz olduğunu ifade ederek itirazda bulanacaktır. Bu örnekte görüldügü gibi, belirlenen illetler birbirleriyle çeliştiği için illetin tespiti zorlaşmakta ve tercihte bulunma zorunluluğu ortaya çıkmaktadır. ${ }^{40}$

Mâverdî, hafî kıyasın bu türüne dayanılarak ne icmâın oluşacağını ne hâkimin verdiği hükmün bozulacağını ne de umumi lafızların tahsis edilebileceğini belirtmektedir. ${ }^{41}$

3. Manası (illeti) karışı/müştebih olan hafî kıyas. Bu kıyas türünde hem nassın kendisi hem de o nassın illeti istidlâle ihtiyaç duymaktadır. Mâverdî hafî kıyasın bu çeşidi için şu rivâyeti örnek olarak zikretmiştir: Adamın biri bir köle satın aldı. Onu kullandı (ondan istifade etti). Sonra kölede bir kusur buldu ve onu aldığı kişiye geri iade etti. Kölenin sahibi Hz. Peygamber'e giderek “Ey

38 Ebu'l-Velîd Muhammed b. Ahmed İbn Rüşd, Şerhu Bidâyeti'l-Müctehid ve Nihâyetü'lMüktasîd, thk. Abdullah el-Abâdî (Kahire: Dâru's-Selâm, 1995), 3: 1568-1571; Cessâs, Şerhu Muhtasari't-Tahâvî, 3: 19.

39 Serahsî, Usûl, 2: 245; Âmidî, el-İhkâm, 5: 1975; İbn Hâcib, Muhasar, 2: 1151; Îcî, Şerhu'l-Adud, 2: 876; Nemle, el-Muhezzeb, 2258.

40 Mâverdî, Edebu'l-Kâdî, 1: 597-598.

41 Mâverdî, Edebü'l-Kâdî, 1: 597-598. 
Allah'ın Rasûlü bu adam kölemden istifade etti." deyince, Hz. Peygamber (s.a.v); "الخراج بالضمان: Harac, damân karşıllğ̆ındadır." şeklinde cevap verdi. ${ }^{42}$ Bu hadisin hem kendisi (nass) hem de illeti istidlâle ihtiyaç duymaktadır. İlk önce bu hadiste geçen "الخراج" kelimesinden maksadın ne olduğunun tespit edilmesi gerekmektedir. İstidlal sonucu harâc lafzının menfaat, damân kelimesinin ise satım sözleşmesi olduğu belirlenmiştir. Bundan sonra illetin tespitine geçilmiştir. İstidlâl sonucu belirlenen illet hususunda görüş ayrıllğı meydana gelmiştir. Bazıları menfaati neticeleser olarak kabul etmiştir. Yani damânın illeti neticeleserdir. Bu kişilere göre, örneğin herhangi biri bir inek satın alsa bu inek müşterinin elinde bulunduğu süre içinde doğursa ve müşteri onun sütünden içse, sonra bir ayıbına vakıf olup geri verse, satan kimse, ineğin yavrusunu ve sütün parasını geri isteyemez. Bazıları menfaati, aslın cinsine muhalif olan şey şeklinde anlamışlardır. Bu kişilere göre, damânın illeti, bir şeyin kendi cinsine muhalif olmasıdır. Bunlara göre satıcı müşteriden yavruyu isteyebilir fakat sütün parasını isteyemez. Şâfîi, menfaati nemâ' (maldan doğan ziyâdelik) olarak ta'lîl ettiği için ineğin sütü ve yavrusunun müşteriye ait olacağına hükmetmiştir. ${ }^{43}$

Mâverdî, hafi kıyasın bu türünde, aslın hükmü üzerinde icmâın oluşabileceğini ancak manası (illeti) üzerinde oluşamayacağını ifade etmektedir. Mâverdî’ye göre kıyasın bu çeşidi ne hâkimin verdiği hükmü bozabilir ne de umumi lafızları tahsis edebilir. Hafî kıyasın bu türü, bundan önceki kıyas türleri içerisinde en zayıf olanıdır. ${ }^{44}$

\section{2. Şebeh Kıyası}

Sözlükte "benzeme" 45 anlamına gelen şebeh, ortak özellik sebebiyle fer'in asla ilhak edildiği tüm kıyaslar için kullanılmakla birlikte bunun tanımı hususunda usûlcüler arasında görüş ayrılığ 1 bulunmaktadır. ${ }^{46}$ Şâfîi, bu kıyas türü için: "kıyas yapanların bazen ihtilafa düştükleri yer burasıdır" diyerek bu tür kıyas

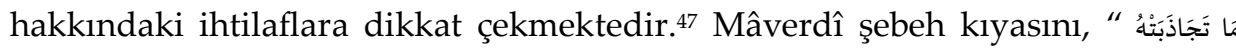

İbn Mace, Ticârât, 43.

43 Mâverdî, Edebü'l-Kâdî, 1: 599-600.

44 Mâverdî, Edebü'l-Kâdî, 1: 600.

45 İbn Manzûr, Lisanü'l-Arab, 4: 2189.

46 Şebeh kıyası hakkında yapılan farklı tanımlar ve değerlendirmeler için bkz: Âmidî, elİhkâm, 4: 1796-1800.

47 Muhammed b. İdris eş-Şâfiî, er-Risale, thk. Ahmed Muhâmmed Şakir (Kahire: Dâru'nNubelâ, 2016), 434 . 


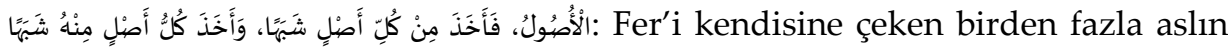
bulunması nedeniyle, her birinin bir benzerlik yönünün bulunduğu kıyas"48 şeklinde tanımlamıştır.

Mâverdî şebeh kıyasını, tahkîk kıyası ve takrîb kıyası şeklinde iki kısma ayırmıştır:

\subsubsection{Tahkîk Kıyası}

Sözlükte "onaylamak" 49 anlamına gelen tahkik lafzı kıyas kelimesi ile bir-

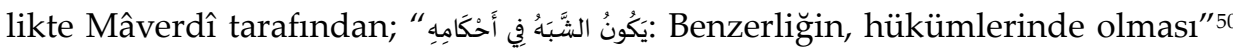
şeklinde tanımlanmıştır. Yani fer, hükümleri bakımından birbirinden farklı olan asıllara benzemektedir.

Mâverdî tahkîk kıyasını üç kısma ayırarak incelemiştir.

1. İki farklı asla benzeyen fer'in, bunlardan birisine benzetilmesi durumunda hükmünün bozulacağı, diğerine benzetilmesi halinde hükmünün bozulmayacağı tahkîk kıyası. Bu durumda fer'in asıllardan birisine daha fazla benzemesi dikkate alınmaz, hangi aslın hükmünün fer'e verilmesi aslın hükmünü bozmuyorsa o hüküm fer'e verilecektir. Mâverdî tahkik kıyasının bu türü için kölenin mülkiyeti hakkındaki hükmü örnek olarak zikretmiştir. Kölenin mülk edinme hakkının olup olmadığı konusunda biri hür kişi diğeri hayvan olmak üzere kıyas yapılabilecek iki asıl bulunmaktadır. Köle, mükellef olması açısından hür kişilere, başkasının mülkü olması bakımından ise hayvanlara benzemektedir. Köle ile hür kişi arasındaki benzerlik köle ile hayvan arasındaki benzerlikten daha fazla olmakla birlikte kölenin hür kişiye kıyas edilmesinin önünde bir engel bulunmaktadır ki o da kölenin mirasçı olamamasıdır. Buna karşın kölenin hayvana kıyas edilmesinde herhangi bir engel söz konusu değildir. Bu sebeple köle hayvana kıyaslanarak onun (kölenin) mülkiyet edinme hakkının bulunmadığ 1 hükmüne varılmıştır. ${ }^{51}$

\footnotetext{
Mâverdî, Edebü'l-Kâdî, I, 600.

İbn Manzûr, Lisanü'l-Arab, 2: 942.

50 Mâverdî, Edebü'l-Kâdî, 1: 601.

51 Mâverdî, Edebü'l-Kâdî, 1: 601-602.
} 
2. Fer'in, iki asıldan birisine daha fazla benzemesiyle yapılan tahkik kıyası. Tahkîk kıyasının bu türünde fer'in aralarından birine benzetilmesiyle hükmü bozulmayan iki aslı bulunmakta ancak bunlardan birisine diğerinden daha fazla benzemesi söz konusu olmaktadır. Bu durumda fer', en çok hangi asla benziyorsa ona kıyas edilir. Mâverdî tahkik kıyasının bu türü için kölenin organlarına zarar verilmesi durumunda zarar verene nasıl bir ceza takdir edileceği konusundaki hükmü örnek olarak zikretmiştir. Köle, mülkiyete ve mirasa konu olması açsından hayvana; insan olması, mükellef olması ve öldürülmesi durumunda öldürene ceza ve kefaretin gerekli olması bakımından ise insana benzetilmektedir. Hür kişinin asıl olarak kabul edilmesi halinde kölenin organlarına verilen zarar kısası; hayvanın asıl kabul edilmesi durumunda ise kölenin zarar gören organlarının kıymetinin tazmini gerekecektir. Burada kölenin insana benzerlik yönü daha fazla olduğu için onun organlarına zarar verilmesi durumunda köle, hür kişiye kıyas edilecektir. ${ }^{52}$

3. Fer'in hükmünün, sıfatları farklı olan iki asla benzemesiyle yapılan tahkik kıyası. Tahkîk kıyasının bu türünde fer'in hükmü, sıfatları farklı olan iki asıl arasında gidip gelmekte ve iki sıfattan her birinin tamamı değil, bir kısmı fer'de bulunmaktadır. Bu durumda fer', iki aslın sıfatlarından hangisi daha galip (baskın) geliyorsa onun hükmünü alacaktır. Mâverdî, tahkik kıyasının bu türü için hem odun hem de yiyecek maddesi olan karahalile ve sakamonyayı (mahmudiye otu) örnek olarak zikretmiştir. Bu iki madde odun olmaları bakımından ribevî kabul edilmezken, yiyecek maddesi olmaları açısından ise ribevî kabul edilmektedir. Bu iki maddede galip olan sifat yiyecek maddesi olma vasfi olduğundan, gıda maddelerine kıyasla bunlarda faizin gerçekleşeceği kanaatine ulaşılmıştır. ${ }^{53}$

\subsubsection{Takrîb Kıyası}

Sözlükte "yaklaşmak" anlamına gelen takrîb lafzı, kıyas kavaramı ile bir-

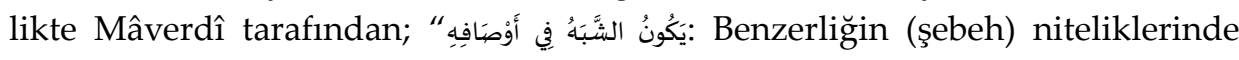
meydana geldiği kıyas" ${ }^{54}$ şeklinde tanımlanmıştır. Kıyasın bu türünde fer, sıfatları bakımından birbirlerinden farklı olan asıllara benzemektedir.

52 Mâverdî, Edebü'l-Kâdî, 1: 602.

53 Mâverdî, Edebü'l-Kâdî, 1: 602-603.

54 Mâverdî, Edebü'l-Kâdî, 1: 604-605. 
Mâverdî takrîb kıyasını üç kısma ayırmıştır:

1. Fer'in, sıfatları farklı olan iki asla benzediği ve bu asılların iki sıfatını da ihtiva ettiği takrib kıyası. Bu durumda fer', galip (baskın) olan sıfata göre hüküm alacaktır. Mâverdî, bu konunun daha iyi anlaşılabilmesi için biri aklî diğeri şer'î olmak üzere iki örnek vermiştir: Aklî örnekte hem beyaz hem de siyah niteliğine sahip iki aslı olan bir fer', siyah ve beyaz niteliklerini birlikte taşımaktadır. Bu durumda fer'de siyah ve beyaz renklerden hangisi daha fazla ise onun hükmünü alacaktır. Mâverdî adil olan kişilerin şahitliğinin kabul edilip fasık olan kişilerin şahitliğinin kabul edilmemesini şer'î örnek olarak zikretmiş̧ir. Burada iki asıl söz konususundur. Bunlardan biri âdil diğeri ise fasıktır. İyi olan herkesin - Peygamberlerin dışında - az da olsa günah işlemesi söz konusu olduğu gibi, kötü olan insanlarda da az da olsa iyilik yapma ihtimali söz konusudur. Bu sebeple şahitlerin adalet sahibi olup olmadıkları tespit edi-

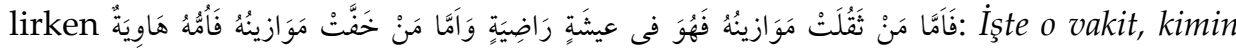
tartıları ă̆ır gelmişse, artık o, hoşnut olacağı bir hayat içinde olacaktır. Ama kimin de tartıları hafif gelirse, işte onun anası (varacağı yer) hâviye'dir" (Kâria 101/6-9) ayeti gereği, iyilik ve kötülüklerden hangisi daha ağır basarsa ona göre hüküm verilecektir..$^{55}$

Mâverdî, kıyasın fer'in illetini asıldan çıkarmak olduğu, kıyasın bu türünde ise tam tersine aslın illetinin fer'den çıkartıldığı gerekçesiyle Ebû Hanife'nin (ö. 150/767) takrîb kıyasının bu türünü kıyas olarak kabul etmediğini nakletmektedir. Ebû Hanife'nin bu görüşünü isabetli görmeyen Mâverdî, burada illetin sıfatının fer'den, hükmün ise asıldan çıkarıldığını, ikisinin bir araya gelmesiyle illetin hükmünün oluştuğunu belirtmektedir. $\mathrm{O}$, buna mutlak suya gül suyu gibi temiz bir şey karıştı̆̆ında suyun tabiatının değişmemesini örnek olarak zikretmiştir. Bu durumda mutlak su daha fazla ise içerisinde bulunan şey temiz olmasa dahi suyun temiz olduğuna hükmedilir. Gül suyunun daha fazla olması durumunda ise mutlak suyun içinde bulunan şeyin temiz olmasına bakılmaz ve suyun temiz olmadığına hükmedilir. Ebû Hanife'nin de bu hüküm konusunda aynı kanaatte olduğunu ifade eden Mâverdî, onun tarafından yapılan itirazın lafzi olduğunu, bunun da bir problem teşkil etmediğini ileri sürmektedir. ${ }^{56}$

55 Mâverdî, Edebü'l-Kâdî, 1: 601.

56 Mâverdî, Edebü'l-Kâdî, 1: 605-606. 
2. Fer'in, nitelikleri farklı iki asla, bu nitelikleri bulundurmadan sıfatlardan birisine diğerinden daha fazla yakınlık göstererek benzediği takrib kıyası. Mâverdî takrib kıyasının bu türüne biri akli diğeri şer'î olmak üzere iki farklı örnek vermiştir. Beyaz ve siyah niteliklerine havi iki asla yeşilin kıyas edilmesini akli örnek olarak zikredilmiştir. Bu iki aslın nitelikleri olan siyahlık ve beyazlıktan hiçbirisi yeşilde bulunmamaktadır. Mâverdî, ihramlı olan kişinin avladığı hayvanın dengi ehli bir hayvanı ceza olarak vermesini öngören ayeti şer'î örnek

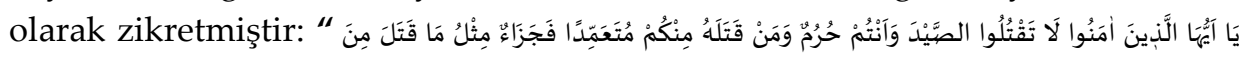

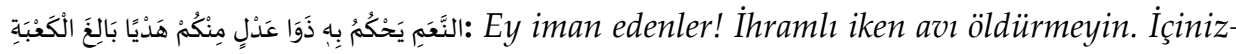
den kim onu kasten öldürürse öldürdü̆g̈̈ hayvanın dengi (ona) cezadır. (Buna) Kâbe'ye varacak bir kurban olmak üzere içinizden adalet sahibi iki kişi hükmeder (öldürülen avın dengini takdir eder)" (Maide 5/95) ayetinde ifade edilen denklik, tüm sıfatlarda söz konusu değildir. Bu durumda ceza takdir edilirken av hayvanına en çok hangi hayvan benziyorsa ona hükmedilecektir. ${ }^{57}$

Ebû Hanife, bu işlemin kıyas olmadığını söylemiştir. Ona göre kıyas, asılda bulunan vasıfların (illet) fer'de de bulunmasıdır. Hâlbuki bu işlemde aslın vasıfları fer'de bulunmamaktadır. Dolayısıyla bu işlemin kıyas olarak adlandırılması durumunda kıyas illetsiz olmuş olur. ${ }^{58}$ Mâverdî, tahkik kıyasının bu türünde illetin bulunmadığı itirazına cevap vermese de İslam'da meselelerin delilsiz olamayacağı noktasından hareketle bu itirazı cevaplandırmaya çalışmıştır. ${ }^{99}$ Ona göre her hâdisenin bir hükmü, her hükmün de bir delili olması gerekmektedir. Herhangi bir mesele ile ilgili kitap, sünnet ve icmâda bir delil bulunmuyorsa kıyasın dışında başka bir delil kalmamış demektir. Bu durumda asla en çok benzeyenin, kıyasın illeti olarak kabul edilmesi durumu ortaya çıkacaktır.60

Bazı Şâfiî âlimlerin kıyasın bu türüne kıyas değil yalnızca içtihat demelerini eleştiren Mâverdî, aslın benzeri meselelere hüküm verilebilmesi için yapılan bu içtihadın bir asla dayanması gerektiğini bunun adının da kıyas olduğunu belirtmektedir. ${ }^{61}$

57 Mâverdî, Edebü'l-Kâdî, 1: 606-607.

58 Cemaleddin Abdurrahman b. Hasan İsnevî, Nihâyetu's-Sûl fî Şerhi Minhâci'l-Vusûl İla İlmi'lUs ûl, thk. Şaban Muhammed İsmail (Beyrût: Daru ibn Hazm, 1999), 2: 827.

59 Birsin, "Ebu'l-Hasan el-Mâverdî'nin Bilgi Anlayışı", 71.

60 Mâverdî, Edebu'l-Kâdî, 1: 606-607.

61 Mâverdî, Edebü'l-Kâdî, 1: 607-608. 
352 • Ebu'l-Hasan el-Mâverdî’ye Göre Kıyasın Tanımı ve Türleri

3. Fer'in, biri kendi cinsinden diğeri kendi cinsinden olmayan iki farklı aslın iki niteliğini barındırarak iki asla benzemesiyle gerçekleşen takrib kıyası. Mâverdî takrib kıyasının bu türü için temizlik (taharet) ile ilgili bir konunun, birinin namaz diğerinin ise temizlik olduğu iki aslının bulunmasını örnek olarak zikretmiştir. Bu durumda, fer' kendi cinsinden olan temizlik ile ilgili asla kıyas edilecektir. ${ }^{62}$

62 Mâverdî, Edebü'l-Kâdî, 1: 608. 


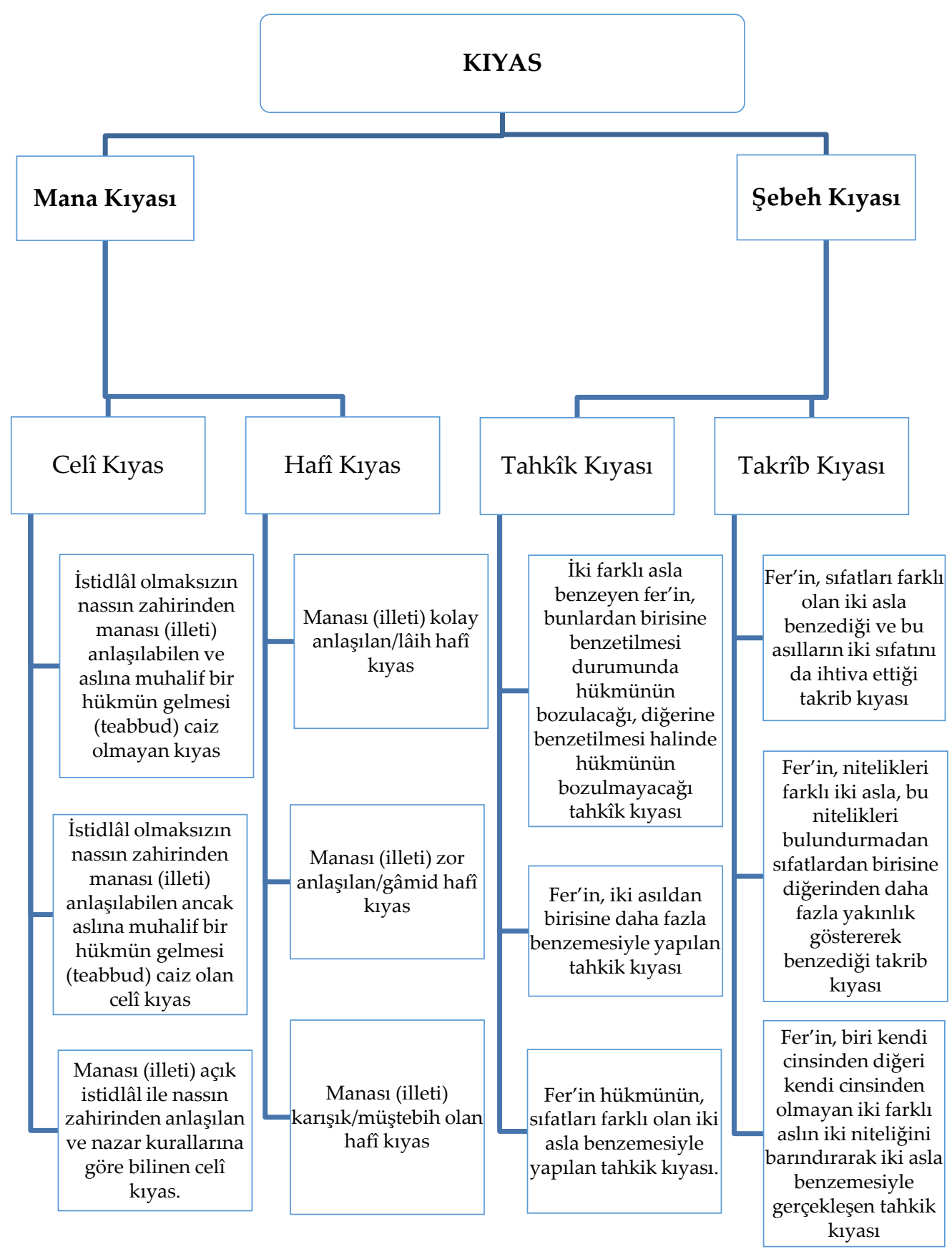




\section{SONUÇ}

Bu çalışmada varılan sonuçlar maddeler halinde şöyle sıralanabilir:

1. İslam hukuk usûlünün tekâmül çağı olarak kabul edilen hicri beşinci asırda yaşayan Mâverdî, kendisinden önceki ilmi müktesebattan da yararlanarak fıkıh usulünün tüm ana konularını sistematik bir şekilde ele almıştır. Ancak o, alışılmışın dışında bu konuları müstakil bir eserde kaleme almak yerine fürui fıkha dair telif ettiği eserin edebu'l-kâdî ana bölümünde incelemeyi tercih etmiştir. Böyle bir yolu tercih etmesi, fikıh usulü ilmini, teorik bir ilim olmaktan çok pratik sorunların çözümünde bilhassa toplumsal meselelerin hallinde ana unsur olarak kabul ettiğini göstermektedir.

2. Mâverdî'nin nasta hükmü belirtilmeyen meselelerin çözümünde başvurulan kıyas işlemini müçtehidin bir faaliyeti olarak görüp bu anlayış istikametinde kıyası tanımlayan selefleri ve çağdaşları ile aynı tanımı yapması, bu konuda onlarla aynı düşünceyi paylaştığını ortaya koymaktadır.

3. Mâverdî'nin kıyası sistematik bir şekilde iki kısma ayırıp her birisini tekrar iki türe ayırdıktan sonra alt gruplara bölmesi ve bu kıyas türlerinin icmâ, nesih, umum lafızların tahsisi gibi konular ile ilişkisini kurması, bu konudaki sistematikliğini ve orijinalliğini ortaya koyduğu gibi, deliller arasındaki ilişki ve hiyerarşiye verdiği önemi de ortaya koymaktadır.

4. Mâverdî, Şâfiî usûlcüler arasındaki görüş ayrılığını ifade etmek istediğinde genellikle herhangi bir isim belirtmezken İbn Ebî Hüreyre söz konusu olduğunda onun ismini zikretmekten geri durmamıştır. Bunun nedeni, İbn Ebî Hüreyre'nin Şâfiı̀'nin görüşlerine aykırı bazı fikirleri dile getirmesidir. Mâverdî, muhalifler tarafından özellikle Şâfii'ye yapılan itirazları da ele alıp cevaplamıştır. Bu gerekçelerden hareketle onun kendi mezhep imamına sıkı bir şekilde tabi olduğu sonucuna varılabilir.

5. Mâverdî, şebeh kıyası ile ilgili görüşlerini açıklarken özellikle Ebû Hanife tarafından yapılan itirazları ele almıştır. Onun, Ebû Hanife'nin itirazlarını ele aldığı şebeh kıyasının türlerini izah ederken konunun daha net anlaşılabilmesi için şer'î örneklerin yanında aklî örneklere başvurması, akla verdiği önemi ortaya koyduğu gibi muhatabının yöntemini de göz önünde bulundurduğunu göstermektedir. 


\section{KAYNAKÇA}

Ebû Süleyman, Abdulvahhab İbrahim. el-Fikru'l-Usûlî-Dirâse Tahliliyye Nakdiyye. Cidde: Daru'ş-Şurûk, 1983.

Akay, İhsan. Şâfiî Usûl Geleneğinde İmâm Şâfiî’ye Muhalif Görüşler. İstanbul: Ensar, 2018.

Âmidî, Seyfeddîn. el-İhkam fî Usûli'l-Ahkâm. Thk. Abdullah b. Ali eş-Şehrânî - Ömer b. Ali es-Selâmî - Osman b. Ahmed el-Asîrî - Ahmed b. Mus'il el-Gâmidî - ve Mu hammed b. Mut'ab Âlkerûm el-Kahtânî. 5 Cilt. Riyâd: Daru'l-Fadîle, 2016.

Basrî, Ebû'l-Hüseyn Muhammed b. Ali el-. Kitabu'l-Mu'temed fî Usûli'l-Fikh. Thk. Muhammed Hamidullah. 2 Cilt. Dımeşk: el-Me'hedu'l-İlmiyyi'l-Fransî li'd-Dirâsâti'1Arabî, 1964.

Birsin, Mehmet. “Ebu'l-Hasan el-Mâverdî’nin Bilgi Anlayışı”. İnönü Üniversitesi Uluslararası Sosyal Bilimler Dergisi 2/1 (2019): 36-76.

Cessâs, Ahmed b. Ali er-Râzî. el-Fusûl fi'l-Usûl. Thk. Uceyl Câsim en-Neşemî. 4 Cilt. Kuveyt: Vezâretü'l-Evkâf ve'ş-Şuûni'l-İslamiyye, 1994.

Cessâs, Ebû Bekir er-Râzî. Şerhu Muhtasari't-Tahâvî fî'l-Fıkhi'l-Hanefî. Thk. İsmetullah İnayetullah Muhammed (son) - ve Sâid Bektaş. 8 Cilt. Beyrût: Daru'l-Beşairi'1İslamiyye, 2010.

Cüveynî, İmâmu'l-Harameyn el-. el-Burhân fî Usûli'l-Fıkh. Thk. Sâlih b. Muhammed b. Avîza. 2 Cilt. Beyrut: Dâru'l-Kütübi'l-İlmiyye, 1997.

Gazalî, Ebu Hamid Muhâmmed b. Muhammed. el-Mustasfâ min İlmi'l-Usûl thk: Süleyman el-Eşkar. Beyrut: Müessesetü'r-Risale, 2010.

İbn Hâcib, Cemâleddîn Ebî Ömer Osman. Muhasaru'l-Müntehe's-Sûli ve'l-Emel fî İlmeyi'l-Usûli ve'l-Cedel. Thk. Nezîr Hamâd. Beyrut: Dâru ibn Hazm, 2006.

İbn Hümâm, Kemâleddîn Muhammaed b. Abdilvahid. et-Tahrîr fî usûli'l-Fıkh el-Câmii Beyne İstilâhayi'l-Haneyiyyeti ve'ş-Şâfiiyye. Mısır: Matbaatu Mustafa el-BabîelHalebî, 1351.

İbn Manzûr. Lisanü'l-Arab. Thk. Abdullah Ali el-Kebir - Muhammed Ahmet Hasbullah Abdullah Ali el-Kebîr - ve Haşim Muhammed eş-Şâzelî. Kahire: Darul Mearif, t.y.

İbn Rüşd, Ebu'l-Velîd Muhammed b. Ahmed. Şerhu Bidâyeti'l-Müctehid ve Nihâyetü'1Müktasîd. Thk. Abdullah el-Abâdî. 4 Cilt. Kahire: Dâru's-Selâm, 1995.

Îcî, Adududdîn Abdurrahman b. Ahmed. Şerhu'l-Adud alâ Muhtasari Muntehe'l-Vusûl ve'l-Emel fî İlmeyi'l-Usûl ve'l-Cedel. Thk. Ali b. Abdirrahman Bessân el-Cezâirî. 2 Cilt. Beyrût: Dâru ibn Hazm, 2016.

İsnevî, Cemaleddin Abdurrahman b. Hasan. Nihâyetu's-Sûl fî Şerhi Minhâci'l-Vusûl İla İlmi'l-Usûl. Thk. Şaban Muhammed İsmail. 2 Cilt. Beyrût: Daru ibn Hazm, 1999. 
Leknevî, Abdulali Muhammed b. Nizâmeddîn. Fevâtihu'r-Rahamût bi Şerhi Müsellemi's-Sübût. Thk. Abdullah Mahmut b. Ömer. 2 Cilt. Beyrut: Dâru'1-Kutubi'1İlmiyye, 2002.

Mâverdî, Ebu'l-Hasan Ali b. Muhammed b. Habib. Edebu'l-Kâdî. Thk. Muhyî Hilâl esSerhân. 2 Cilt. Bağdâd: Matbaatu'l-İrşâd, 1971.

Nemle, Abdülkerim. el-Muhezzeb fî İlmi Usûli'l-Fıkhi'l-Mukâren. 5 Cilt. Riyad: Mektebetü'r-Rüşd, 1999.

Râzî, Fahreddin Muhammed b. Ömer Hüseyin. el-Mahsûl fî İlmi-Usûli'l-Fıkh. Thk. Taha Câbir Feyyâz Alvânî. 6 Cilt. Beyrût: Müessesetü'r-Risale, t.y.

Serahsî, Şemsü'l-Eimme Muhammed b. Ahmed. Usûlü's-Serahsî. Thk. Ebû'l-Vefâ elAfgânî. 2 Cilt. Beyrût: Daru'l-Kutubi'l-İlmiyye, 1993.

Şâfiî, Muhammed b. İdris er-Risâle. Thk. Ahmed Muhâmmed Şakir. Kahire: Dâru'nNubelâ, 2016.

Şirazî, Ebu İshak İbrahim b. Ali. el-Lum'a fi Usûli'l-F1kh. Thk. Muhyiddin Dîb mıstu - ve Yusuf Ali Bedivi. Beyrût: Dâru ibn Kesir, 1995.

Temizkan, Ahmet. İmam Şâfîi’nin Usûl Anlayışında Şereê̂ Delillerin Teâruzu ve Çözüm Yolları. Dicle Üniversitesi SBE, 2019.

Yiğit, Metin. “İmâm Şâfiî̀'de Arapça Vurgusu ve Lafız-Mana Dengesi”. Dicle Üniversitesi İlahiyat Fakültesi Dergisi 11/2 (2009): 55-86.

Zemahşerî, Ebu'l-Kasım Mahmud b. ömer. Esasü'l- Belağa. Beyrut: Daru'1-Kutubi'lİlmiyye, 1998.

Zerkeşî, Bedruddîn b. Bahâdır. el-Bahru'l-Muhît fî Usûli'l-Fıkıh. Thk. Abdussettar Ebû Gudde. 6 Cilt. Kuveyt: Vezaretü'1-Evkaf ve'ş-Şuunü'l-İslamiyye, 1992. 